Journal of Computer Networks, Architecture and High Performance Computing

Volume 3, Number 2, July 2021

https://doi.org/10.47709/cnahpc.v3i2.980

Submitted : 14 June 2021

Accepted : 5 July 2021

Published : 15 July 2021

\title{
Web-Based Rice Disease Diagnosis Expert System Using Fuzzy Tsukamoto Method and K-Nearest Neighbor Algorithm
}

\author{
Fefi Hades Tawarai ${ }^{1)}$, Fauziah $^{2)}$, Andrianingsih ${ }^{3)}$ \\ 1)2)3) Universitas Nasional, Indonesia \\ ${ }^{1)}$ fefihadess92@gmail.com, ${ }^{2)}$ fauziah@civitas.unas.ac.id, ${ }^{3)}$ andrianingsih@civitas.unas.ac.id
}

\begin{abstract}
Technology today is growing rapidly from year to year, not least started to spread to the agricultural sector. With the information technology making society more easily in search of information via the internet from your smart device. The goal of this study was made to facilitate the community, especially farmers in helping to diagnose diseases and pests in rice plants. Rice plants can be attacked by a wide variety of diseases and pests with a wide variety of symptoms experienced in rice plants. To know the kind of disease on rice plants in the era of technology, it takes an expert system that can help detect the disease in rice plants. In this study, Expert System-Based Website using Tsukamoto Fuzzy method and the Algorithm of K-Nearest Neighbor whose purpose is to help people, especially farmers in diagnosing diseases and pests in rice plants by looking at the symptoms of the attack on the rice plant. Data was obtained from the Research and the Ministry of Agriculture then taken some sample data for testing done. The results of the testing data of this expert system is the result of late diagnosis in diseases of the rice with the symptoms that already exist based on the data that have been obtained with an accuracy rate of $92,88 \%$.
\end{abstract}

Keywords: Expert System, Fuzzy Tsukamoto, Web Based, K-Nearest Neighbor, Rice Plant

\section{INTRODUCTION}

The agricultural sector is an important element in human life, because of agricultural produce crops that will be a staple food of man. Without the results of the harvest from the farm, we will not be able to enjoy the daily staple food that have been consumed (Nurdiawan, 2018). One of the results of the harvest is important in everyday life is Rice. When the rice is ready to harvest and into the rice, then the rice will be sent to all region in Indonesia that will be consumed by the entire community in Indonesia (A. Saepulloh, 2016)

The results of the rice harvest is of course not always produce the best, sometimes in the process of the growth of the rice also has constraints such as pests and diseases. Although rice plants is the main priority as a daily staple food, but the pests and diseases that often attack rice plants make losses on farmers because it will result in crop failure (Y. Wendra, 2020).

To help resolve the issue of rice farmers, in this study the authors use the method of Fuzzy Tsukamoto and Algorithms K-Nearest Neighbor (KNN) in the study of expert systems web-based diagnosis of diseases in rice plant (Pajapati et al., 2017). The expected result is the diagnosis of disease of rice, which is obtained based on the symptoms that attack on rice plant. The goal is that when achieved diagnostics diseases of the rice plant in order to quickly given handling is appropriate in order to prevent the occurrence of crop failure (Sethy et al., 2020).

In a previous study entitled Information System for Detecting Pests and Diseases of Rice Plants Using the Android-Based Fuzzy Tsukamoto Method (Puryono, 2018) discussed the information system for diagnosing rice diseases using the fuzzy Tsukamoto method. The information system helps farmers detect pests and diseases on rice plants using Smart Phone media because the expert system is based on Android (Asmira \& Syamsul Alam, 2020). Another study with the same topic, entitled Web-Based System for Diagnosing Rice Diseases with Forward and Backward Chaining (Honggowibowo, 2009) discusses a web-based expert system for diagnosing rice diseases using Forward and Backward Chaining methods. Then another study entitled Accuracy in Identifying Rice Plant Diseases Using Fuzzy Method (Handayani \& Nurcahyo, 2021) which discusses the accuracy of disease diagnosis in rice plants using the fuzzy method with the accuracy level of each pest symptom, namely TUNGRO disease $=4.5$, Brown spots $=4.5$, and Bacterial blight $=4.625$. Another next study entitled Expert System for Diagnosing Rice Pests and Diseases Using Bayes Method (Wulandari et al., 2019) which discusses the determinants of disease in rice plants using the

* Corresponding author

This is an Creative Commons License This work is licensed under a Creative

Commons Attribution-NoDerivatives 4.0 International License. 


\section{Journal of Computer Networks, Architecture and High Performance Computing}

Volume 3, Number 2, July 2021

https://doi.org/10.47709/cnahpc.v3i2.980
Submitted : 14 June 2021

Accepted : 5 July 2021

Published : 15 July 2021

Bayes method. Another research with the same topic entitled Diagnosing Pests and Diseases in Rice Using the Naïve Bayes and K-Nearest Neighbor Methods (Bianome et al., 2020) which discusses the rice plant disease diagnosis system using the Naïve Bayes and K-Nearest Neighbor methods and has a high level of accuracy range from $70 \%$ to $100 \%$.

From previous studies with a variety of methods, this research will make a research with the topic of same detection system disease in rice plants using the merger method of Fuzzy Tsukamoto and Algorithms K-Nearest Neighbor (K-NN).

\section{Fuzzy Tsukamoto}

\section{LITERATURE REVIEW}

The Tsukamoto method is one of several fuzzy approach methods. In this method, Tsukamoto uses the rule of cause and effect or "if-then" (Nugraha et al., 2019). The Tsukamoto fuzzy calculation method uses a representation of the rules formed by the fuzzy set, then the degree of membership is calculated according to the rules that have been made. On the Tsukamoto method, each Rule is represented by a set of Fuzzy membership functions are monotonous called fuzzification. (Puryono, 2018).

\section{K-Nearest Neighbor (K-NN)}

$\mathrm{K}-\mathrm{NN}$ is a classification method for objects based on data from learning the nearest distance value. K-NN is used to overcome the identification of values measured both qualitatively and quantitatively (Yhurinda et al., 2019). $\mathrm{KNN}$ is a supervised learning algorithm where the result of the query instance that a new classified based on the majority of the categories on the algorithm of KNN. Where is the class that appears most which will be the class the results of the classification (Purnamawati et al., 2020).

\section{METHOD}

The method used is Fuzzy and the K-Nearest Neighbor (K-NN) algorithm where the Fuzzy method is to determine the MB (Measure of Belief) and MD (Measure of Disbelief) values which include determining input and output and determining Tsukamoto inference. Then the K-Nearest Neighbor (K-NN) algorithm is used to determine the level of accuracy in percentage units.

\section{Fuzzy Tsukamoto}

Research on Expert Systems Web-Based method using Fuzzy Tsukamoto. Logic and the theory of Fuzzy set has great potential in determining the uncertainty in a data (Puryono, 2018)

Several reasons why this research uses fuzzy logic:

1. The logic concept is easy to understand

2. Flexible use of logic

3. Fuzzy logic is able to provide very complex nonlinear function modeling

4. Does not require training to model the knowledge possessed by experts.

The defuzzification process is stated in the following equation:

Where :

$$
Z=\frac{\sum \alpha(i) \cdot z(i)}{\sum z(i)}
$$

$$
\begin{aligned}
& \alpha=\text { alpha } \\
& \mathrm{z}=\text { crisp value } \\
& \mathrm{Z}=\text { fuzzification }
\end{aligned}
$$

\section{Fuzzy Tsukamoto Steps} diagram.

In this study, Fuzzy Tsukamoto has some important grooves which are shown by Fuzzy Tsukamoto workflow 
Journal of Computer Networks, Architecture and High Performance Computing

Volume 3, Number 2, July 2021

https://doi.org/10.47709/cnahpc.v3i2.980

Submitted : 14 June 2021

Accepted : 5 July 2021

Published : 15 July 2021

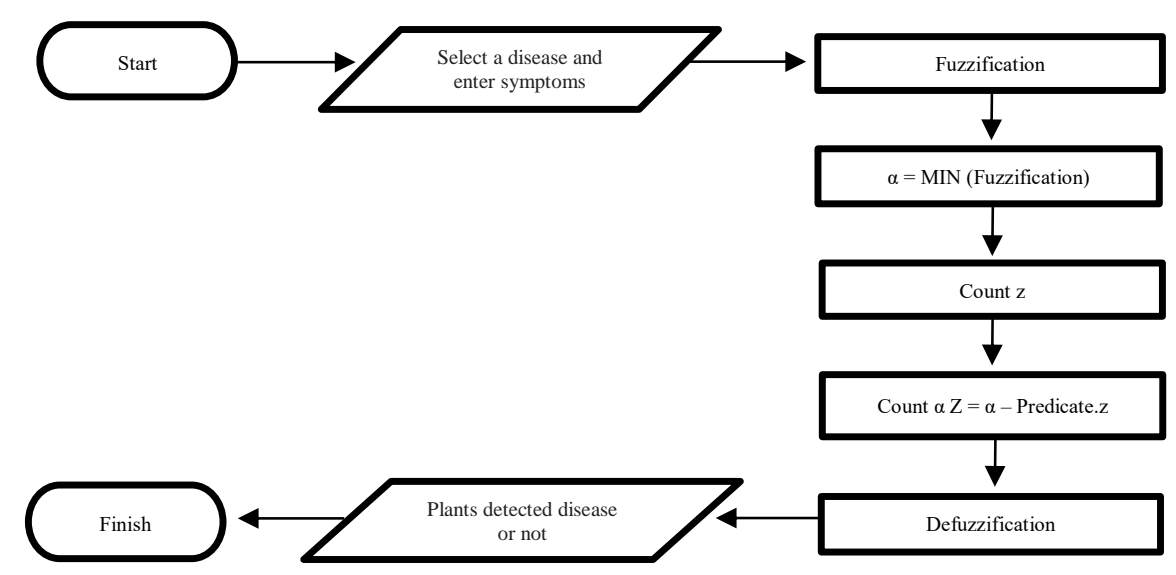

Fig 1. Fuzzy Tsukamoto Steps

\section{K - Nearest Neighbor (K-NN)}

The K-NN method is a method of classifying learning data objects with the closest distance. The K-NN method is applied to solve quantitative and qualitative identification problems (Purnamawati et al., 2020). The K-NN algorithm is a relatively simple algorithm because this algorithm is a lazy learning algorithm. K-NN Algorithm does not use training samples (data) for testing purposes. Most of the time is used for classification (PRIMARTHA, n.d.)

Steps in the K-NN algorithm:

1. Specify the parameter $\mathrm{K}$

2. Calculate the distance between test data and all training data

3. The distances are sorted in descending order

4. Determine the closest distance to the order K

5. Find the class that matches the distance that has been sorted

6. Find the highest number of classes and then classify the data

The K-NN equation formula is as follows:

$$
d_{i}=\sqrt{\sum_{i=1}^{p}\left(x_{2 i}-x_{1 i}\right)^{2}}
$$

Where :

$$
\begin{aligned}
& x_{1}=\text { data training } \\
& x_{2}=\text { data testing } \\
& \mathrm{d}=\text { distance } \\
& \mathrm{i}=\text { data variable } \\
& \mathrm{p}=\text { data dimension }
\end{aligned}
$$

\section{Algorithm K-NN Steps} diagram.

In this study, the K-NN algorithm has a flow that will be illustrated with a K-Nearest Neighbor flowchart 
Journal of Computer Networks, Architecture and High Performance Computing

Volume 3, Number 2, July 2021

https://doi.org/10.47709/cnahpc.v3i2.980

Submitted : 14 June 2021

Accepted : 5 July 2021

Published : 15 July 2021

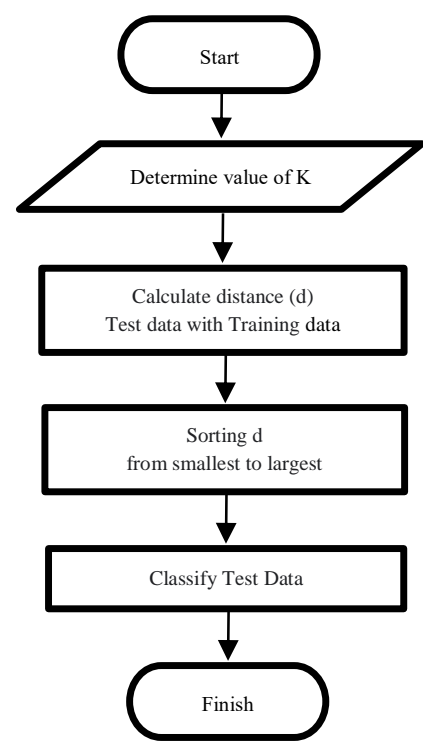

Fig 2. Algorithm K-NN Steps

\section{RESULT}

This research method using Fuzzy Tsukamoto and Algorithms K-Nearest Neighbor (KNN) which then generates the average value of the testing data is taken from the case on the Research and the Ministry of Agriculture of the Republic of Indonesia in the period of 2 years a total of 153 cases. The authors take the 8 samples of pests and diseases in rice plants which are then tested using Cross Validating Indexing are then obtained an average value of $92,88 \%$ in the process of testing.

\section{DISCUSSIONS}

Expert system for diagnosis of diseases of the rice plant Tsukamoto Fuzzy method and the algorithm of K-Nearest Neighbor aims to help facilitate the rice farmers in diagnosing diseases that attack rice plants. This expert system is web-based, so that is easily accessible using a Smart Phone by the farmers and the farmers could more quickly deliver the handling on the results of planting them in order to avoid crop failure.

At the analysis stage, the authors use the data obtained from various sources about the types of diseases in rice plant. Author penjabarkan separately Pests and Diseases in table 1 and the Symptoms of the Disease in table 2 of the rice plant, then the author to formulate the overall symptoms in diseases of rice with table 3 below.

Table 1

Pest and Diseases of Rice Plant

\begin{tabular}{cl}
\hline \multicolumn{2}{c}{ Pest and Diseases of Rice Plant } \\
\hline \hline Code & \multicolumn{1}{c}{ Pest and Diseases } \\
\hline H1 & Caterpillar and Rice Borer \\
H2 & Blas Pest \\
H3 & Leaf Hawar \\
H4 & Tungro \\
H5 & Field Mouse \\
H6 & Golden Snail \\
H7 & Bad-Smell Grasshopper \\
H8 & Brown Planthoppers \\
\hline \hline
\end{tabular}


Journal of Computer Networks, Architecture and High Performance Computing

Volume 3, Number 2, July 2021

https://doi.org/10.47709/cnahpc.v3i2.980

Submitted : 14 June 2021

Accepted : 5 July 2021

Published : 15 July 2021

Table 2

Rice symptoms and diseases

\begin{tabular}{cl}
\hline \hline Code & \\
\hline \hline G01 & Brown Sapling Leaves \\
G02 & White Panicles \\
G03 & The appearance of small purple spots on young leaves (Blas Leaf) \\
G04 & Brown Neck (Blas Neck) \\
G05 & The tip of the stalk is rotten \\
G06 & Gray spots on the leaf margin \\
G07 & Leaves are yellow to orange \\
G08 & The number of tillers is reduces \\
G09 & Grown is stunted so that plant is stunted \\
G10 & The young leaves are somewhat curled \\
G11 & Plant damage starts from the center of the plot then extend to the edges \\
G12 & Young Plants are eaten until the run out until the clumps disappear \\
G13 & Rice change colors, floats, and is empty \\
G14 & Rice floats and empty \\
G15 & Dwarf plant and rotting at the base or dead seeds \\
G16 & Root rot \\
G17 & Dead seeds \\
\hline \hline
\end{tabular}

Table 3

Symptoms of Rice Pests and Diseases

\begin{tabular}{lll}
\hline \hline \multicolumn{1}{c}{ Pest - Diseases } & \multicolumn{1}{c}{ Indications } & \multicolumn{1}{c}{ Damaged Parts } \\
\hline \hline Caterpillar - Rice Borer & Brown sapling leaves & Leaf \\
Caterpillar - Rice Borer & White Panicles & Rice Flower \\
Hama Blas & Blas Leaf : the appearance of small purple spots on young leaves & Leaf \\
Hama Blas & Neck Blas : brown & Rice Flower \\
Hama Blas & The tip of the stalk is rotten & Plant Stem \\
Bacterial Leaf Blight & Gray spots on the edges of the leaves & Leaf \\
Tungro & Leave are yellow to orange & Midrib \\
Tungro & The number of tillers is reduced & Midrib \\
Tungro & Growth is hampered to dwarf plants & Midrib \\
Tungro & The young leaves are somewhat curled & Leaf \\
Field Mouse & Plant damage start from the center of the plot, then extends to the edges & Rice Field \\
& & \\
Golden Snail & Young plants are eaten until they run out until the clumps & Plant Stem \\
Bad-Smell Grasshopper & Rice change color & Leaf \\
Bad-Smell Grasshopper & Rice empty and floats & Rice \\
Dwarf Diseases & Dead seeds & Rice \\
\hline \hline
\end{tabular}


Journal of Computer Networks, Architecture and High Performance Computing

Submitted : 14 June 2021

Volume 3, Number 2, July 2021

https://doi.org/10.47709/cnahpc.v3i2.980

Accepted : 5 July 2021

Published : 15 July 2021

\begin{tabular}{lll}
\hline Dwarf Diseases & Root rot & Plant Stem \\
Dwarf Diseases & Dwarf Plants & Plant Stem \\
\hline \hline
\end{tabular}

\section{Testing Process}

At this stage, the method of K-Nearest Neighbor $(\mathrm{K}-\mathrm{NN})$ is going through the process of exercises with data that is already ready. Testing is done by testing the level of accuracy. Each testing process will be validated by dividing the two groups, the test data and data training data. Based on the data obtained from the Research and development of Ministry of Agriculture, a total of 153 cases in years 2018 - 2020 and the authors took samples of 8 of pests and diseases in rice plants. Testing the system using Cross Validation Indexing. In the process of validation testing of pests and diseases of rice used the number of $\mathrm{K}$ value as much as 10 partition where the value of each partition gets the value of accuracy in the form of a percentage value. The results of testing Cross Validation Indexing can be seen with the following table 4 .

Table 4

Cross Validation Indexing

\begin{tabular}{ccccc}
\hline \hline Fold & Amount of Test Data & Total Training Data & $\begin{array}{c}\text { Amount of Correct } \\
\text { Data }\end{array}$ & Accurate \\
\hline \hline 1 & 16 & 137 & 15 & $93,75 \%$ \\
2 & 16 & 137 & 15 & $93,75 \%$ \\
3 & 16 & 137 & 13 & $81,25 \%$ \\
4 & 15 & 138 & 14 & $93,33 \%$ \\
5 & 15 & 138 & 14 & $93,33 \%$ \\
6 & 15 & 138 & 15 & $100,00 \%$ \\
7 & 15 & 138 & 13 & $86,67 \%$ \\
8 & 15 & 138 & 15 & $100,00 \%$ \\
9 & 15 & 138 & 13 & $86,67 \%$ \\
10 & 15 & 138 & 15 & $100,00 \%$ \\
\hline \hline
\end{tabular}

Based on table 4 above, the average value obtained from the Training and Testing process of Indexing test results is $92.88 \%$ with a total test data of 15 to 16 data.

\section{Analysis Result of Fuzzy Tsukamoto}

From the symptoms of rice plants that have been obtained, then an analysis of the MB and MD calculations will be made which will be shown in table 5 below. The results of the analysis with Fuzzy Tsukamoto are as follows: Indication $1:$ Leave are yellow to orange

Indication 2 : Leaf roll

Indication 3 : Stunted growth resulting in stunted plants

Indication 4 : Brown sapling leaves

Table 5

Fuzzy Tsukamoto's calculation results for determining the MD and MB value

\begin{tabular}{cccccc}
\hline \hline Indication & Diseases & $\begin{array}{c}\text { Level of } \\
\text { Indication } \\
\text { Occurrence }\end{array}$ & $\begin{array}{c}\text { Indication } \\
\text { Uniqueness } \\
\text { Level }\end{array}$ & MD & MB \\
\hline \hline Leave are yellow to orange & Tungro & Lots & Medium & 0,2 & 0,8 \\
Leaf roll & Tungro & Lots & High & 0 \\
\hline \hline
\end{tabular}




\section{Journal of Computer Networks, Architecture and High Performance Computing}

Volume 3, Number 2, July 2021

https://doi.org/10.47709/cnahpc.v3i2.980
Submitted : 14 June 2021

Accepted : 5 July 2021

Published : 15 July 2021
Stunted growth resulting in stunted plants

Brown sapling leaves

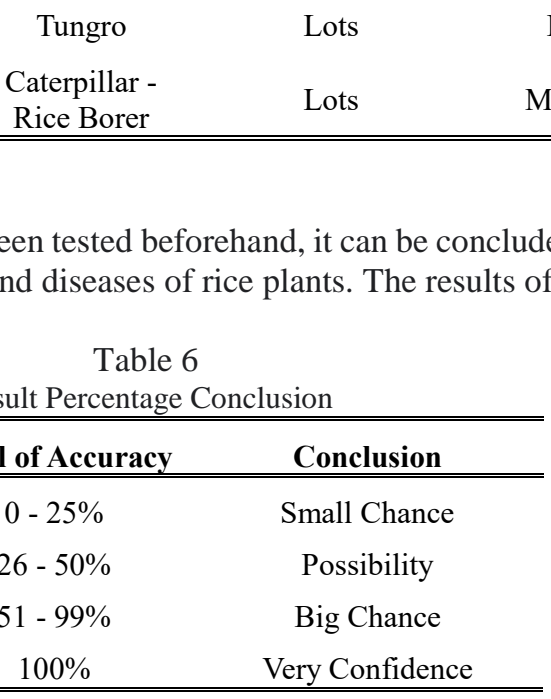

\section{CONCLUSION}

Based on the data that has been tested, the average accuracy obtained from the training and testing process with the K-NN algorithm is $92.88 \%$ with the Indexing test results on 153 test data obtained from the Research and Development Ministry of Agriculture. The test results are 153 data using 10 fold data on test data and training data.

Then for the Fuzzy Tsukamoto method, the results of the Measure of Belief (MB) and Measure of Disbelief (MD) values obtained for symptoms in several samples of diseases and pests in rice plants.

\section{REFERENCES}

A. Saepulloh, D. D. S. F. (2016). Pengembangan Sistem Pakar Diagnosis Penyakit dan Hama Pada Tanaman Padi Varietas Sarinah Berbasis Android. Jurnal Algoritma, 13, 149-156.

Asmira, \& Syamsul Alam. (2020). Aplikasi Sistem Pakar Pengidentifikasi Penyakit Dan Hama Pada Tanaman Padi Berbasis Android. Simkom, 5(2), 19-27. https://doi.org/10.51717/simkom.v5i2.44

Bianome, R. M., Nabuasa, Y. Y., \& Sina, D. R. (2020). Diagnosa Hama Dan Penyakit Pada Tanaman Padi Menggunakan Metode Naive Bayes Dan K-Nearest Neighbor. Jurnal Komputer Dan Informatika, 8(2), 156162. https://doi.org/10.35508/jicon.v8i2.2906

H. B. Prajapati, J. P. Shah, V. K. D. (2017). Detection and classification of rice plant diseases. Intell. Decis. Technol, $11,357-373$.

Handayani, S., \& Nurcahyo, G. W. (2021). Accuracy in Identifying Rice Plant Diseases Using Method Fuzzy. 13(1), 33-41.

Honggowibowo, A. S. (2009). Sistem Pakar Diagnosa Penyakit Tanaman Padi Berbasis Web Dengan Forward Dan Backward Chaining. TELKOMNIKA (Telecommunication Computing Electronics and Control), 7(3), 187. https://doi.org/10.12928/telkomnika.v7i3.593

Nugraha, E., Wibawa, A. P., Hakim, M. L., Kholifah, U., Dini, R. H., \& Irwanto, M. R. (2019). Implementation of fuzzy tsukamoto method in decision support system of journal acceptance. Journal of Physics: Conference Series, 1280(2). https://doi.org/10.1088/1742-6596/1280/2/022031

Nurdiawan, O. (2018). Penerapan Sistem Pakar Menggunakan Metode Fuzzy Sugeno Identifikasi Tanaman Padi. JATISI (Jurnal Tek. Inform. Dan Sist. Informasi), 5, 45-59.

PRIMARTHA, R. (n.d.). BUKU ALGORITMA MACHINE LEARNING. In ALGORITMA MACHINE LEARNING. Penerbit Informatika.

Purnamawati, A., Nugroho, W., Putri, D., \& Hidayat, W. (2020). Deteksi Penyakit Daun Pada Tanaman Padi Menggunakan Algoritma Decision Tree, Random Forest, Naïve Bayes, Svm Dan Knn. Info Tekjar : Jurnal Nasional Informatika Dan Teknologi Jaringan, 5(1), 212-215. 
Journal of Computer Networks, Architecture and High Performance Computing

Volume 3, Number 2, July 2021

https://doi.org/10.47709/cnahpc.v3i2.980

Submitted : 14 June 2021

Accepted : 5 July 2021

Published : 15 July 2021

Puryono, D. A. (2018). Sistem Informasi Pendeteksi Hama Penyakit Tanaman Padi Menggunakan Metode Fuzzy Tsukamoto Berbasis Android. 10(2), 63-69. https://doi.org/10.31219/osf.io/hpk5s

Sethy, P. K., Barpanda, N. K., Rath, A. K., \& Behera, S. K. (2020). Image Processing Techniques for Diagnosing Rice Plant Disease: A Survey. Procedia Computer Science, 167(2019), 516-530. https://doi.org/10.1016/j.procs.2020.03.308

Wulandari, S., Noor Fajrian, M., Wardhana Kusuma, A., \& Kusrini. (2019). Sistem Pakar Diagnosa Hama Dan Penyakit Tanaman Padi Dengan Metode Bayes. Jurnal INFORMA Politeknik Indonusa Surakarta, 5(24427942), 59-64.

Y. Wendra, D. A. (2020). Metode Case Based Reasoning Untuk Identifikasi Penyakit Tanaman Padi. Jursima, 8, 103110.

Yhurinda, A. Putri, P. Sodik, A. A. (2019). Identifikasi Penyakit Tanaman Kopi Arabika dengan Metode K-Nearest Neighbor (KNN). Seminar Nasional Sains Dan Teknologi Terapan VII, 795-764. 